University of Massachusetts Amherst

From the SelectedWorks of Julie Hemment

2004

\title{
Global Civil Society and the Local Costs of Belonging: Defining 'Violence Against Women' in Russia
}

Julie D Hemment 
Global Civil Society and the Local Costs of Belonging: Defining Violence against Women in Russia

Author(s): Julie Hemment

Reviewed work(s):

Source: Signs, Vol. 29, No. 3 (Spring 2004), pp. 815-840

Published by: The University of Chicago Press

Stable URL: http://www.jstor.org/stable/10.1086/381104

Accessed: 06/03/2013 11:02

Your use of the JSTOR archive indicates your acceptance of the Terms \& Conditions of Use, available at http://www.jstor.org/page/info/about/policies/terms.jsp

JSTOR is a not-for-profit service that helps scholars, researchers, and students discover, use, and build upon a wide range of content in a trusted digital archive. We use information technology and tools to increase productivity and facilitate new forms of scholarship. For more information about JSTOR, please contact support@jstor.org. 


\section{Global Civil Society and the Local Costs of Belonging: Defining Violence against Women in Russia}

n May 1998 activists from crisis centers all over Russia gathered in Moscow for a conference to discuss the formalization of their thus-far loose network into a national association. The conference was a veritable gala. I was stunned to see almost all of my Moscow-based women's movement acquaintances, as well as representatives of the main international foundations and agencies (the Ford Foundation, the Open Society Institute, the American Bar Association, the British Embassy, Amnesty International). Everybody who was anybody in the field of women's community activism and development was there.

At the conference, the theme of universalism sounded loud. The first speakers-mostly representatives of international agencies-emphasized cross-cultural commonality. One of the first to the podium was a British woman, a representative of an expatriate club and a longtime benefactor of antiviolence campaigns. As she put it, "Violence against women is not a Russian problem but an international problem, affecting women of all religious and national backgrounds. We are all vulnerable to violence from men; most of us in this room will have experienced violence at some stage in their lives." She offered words of encouragement to the new network"my point is that we were where you are now." Her remarks were intended to bring the women in the room together. They were met, however, with

This essay is based on nineteen months of ethnographic fieldwork conducted in Moscow, Tver', and Pskov between 1995 and 2001; I dedicate it with gratitude to Valentina Uspenskaia and Oktiabrina Cheremovskaia. I am grateful to the Cornell Graduate School, the Einaudi Center for International Studies, and the Cornell University Peace Studies Program for financial support. This piece has benefited from the input of numerous colleagues. I am grateful to James Richter for his observations and insights about the crisis center network and contention about the campaigns. I would like to thank Elizabeth Armstrong, Nanette Funk, Davydd Greenwood, Nancy Ries, and particularly Michele Rivkin-Fish for their thoughtful and critical engagement with earlier drafts and for their encouragement of these ideas. Finally, I would also like to thank the editors of Signs and the reviewers for their detailed comments.

[Signs: Journal of Women in Culture and Society 2004, vol. 29, no. 3]

(C) 2004 by The University of Chicago. All rights reserved. 0097-9740/2004/2903-0007\$10.00 
weary frustration by some attendees. An activist of a Moscow-based group with whom I was well acquainted muttered "I always switch off when foreigners speak"; another woman groaned "men are people too." Dissent such as this erupted at the margins (in the coffee breaks, the corridors, in whispered asides), but this remark and these objections remained unheard.

This vignette highlights some of the key tensions of transnational women's activism that this article explores: the divisiveness of Western aid, the ambiguous role of nongovernmental organizations (NGOs), and the local costs of belonging in transnational or global campaigns. The campaign against violence against women is one of the most prominent campaigns of the Russian women's movement. It is one in which almost all the main women's organizations participate, in some form or another (indeed, I was attending the Moscow conference as both researcher and advocate, representing the women's group I worked with to set up a crisis center). However, the ubiquity of the issue in Russia testifies less to local perceptions of needs than to the success of transnational campaigns and the work of international donor agencies. Beyond limited, elite circles, the work of crisis centers is not understood.

This raises thorny questions about women's activism and social movements in contemporary conditions of globalization. The effectiveness of the global women's movement surely rests on its ability to heed local concerns. However, I argue that the campaigns and the logic of grants and funding that drive them impede this process. The framing of violence against women not only screens out local constructions of events, but it deflects attention from other issues of social justice, notably the material forces that oppress women. This is a troubling outcome for a movement that intends to challenge the global inequities that contribute to women's marginalization. It suggests that we need to be more attentive to the context within which feminist initiatives are nested. Examining my own participation in the campaigns as a Western scholar and activist, I argue that we need to interrogate our use of Western feminist models and concepts in order to be responsive to local knowledge and to achieve truly democratic transnational engagements.

Russia offers an interesting vantage point from which to interrogate these processes. Russian women activists are relative newcomers to the international stage; bar a few early connections during the Soviet period, they first entered into dialogue with Western feminists following the collapse of the Soviet Union in 1991. ${ }^{1}$ As walls and boundaries were

\footnotetext{
${ }^{1}$ The official Soviet Women's Committee delegations had connections with some Western feminist activists during the Soviet period. Further, Western feminist texts circulated
} 
dismantled and democratization got underway, feminist scholars and activists rushed to join in solidarity with Russian women; a mass of horizontal relationships formed under the rubric of sister-city schemes, academic exchanges, and, later, NGO activity. This context helps to explain the tone of the British speaker's remarks. The excitement that was generated by the democratic "revolutions" in the Eastern bloc gave rise to a dizzying sense of possibility and a climate of liberal triumphalism that legitimated this stance and these kinds of interventions. ${ }^{2}$ However, contrary to what she supposes, we were not where they are now. A distinct history and a distinct set of gender alignments shape Russian women's activism. What is more, activism around women's issues emerged not only in the context of the euphoria of democratic change but in the context of intense economic dislocation, too. ${ }^{3}$ Women's groups formed in response to the devastation wrought by "shock therapy," the market-oriented economic reforms implemented in the early 1990s by democratic Russian politicians under the tutelage of U.S. and western European economists. These structural adjustment policies led to the dismantling of the social security system and sharp cutbacks in the health care system, affecting women disproportionately. This situation informs women's perceptions of needs and definitions of problems.

The best way to scrutinize and evaluate the effectiveness of transnational campaigns is to examine their local manifestations; this "place-based ethnography" does just that (Escobar 2000). Drawing on nineteen months of ethnographic fieldwork conducted between 1997 and 2001, I examine the new crisis centers from the two vantage points that my research afforded me-high-profile foundation-sponsored events and interactions with provincial women's groups. Presenting insights gained in the context of an action research project that I undertook with one group, this article highlights local contestation about the campaigns, exploring the competing conceptions of the "crisis" facing Russian women that the campaigns have displaced. In highlighting these alternative constructions, it examines the extent to which activists have been able to translate the issue of gendered violence and to root it in their concerns.

clandestinely via samizdat during the 1970s and 1980s, and there were limited connections between individual dissidents and Western feminist activists.

${ }^{2}$ See, e.g., Borneman 1992; Verdery 1996; Wedel 1998; and Berdahl 1999 for critical discussions of this topic.

${ }^{3}$ Recent feminist scholarship has drawn attention to the gendered effects of democratization and transition, pointing to the ways it has marked the demotion of women as a group in Russia and other postsocialist countries (e.g., Bridger, Kay, and Pinnick 1996; Verdery 1996; Watson 1997; Gal and Kligman 2000). 


\section{Whence the transnational campaigns?}

Before considering these local understandings and concerns, I will first subject the campaigns themselves to scrutiny. The presumed transparency of the issue in international development circles is interesting in itself. Since the 1990s, the campaign against violence against women has had broad resonance across locations. It is assumed to address a universal problem, the content of which is assumed and taken for granted, as my opening vignette suggests.

By the late nineties, violence against women was not only a feminist issue that concerned women's groups; it had become an international development issue. It had won broad acceptance at the United Nations and is still prioritized by international foundations that work with women's community groups. The campaigns are determinedly transnational. The formulation (or framing, to use the language of recent social movements theory) of violence against women is deliberately inclusive, pitched in such terms as to encompass diverse social practices-from spousal abuse to female genital mutilation. How was this achieved?

Gendered violence has long been a concern of local women's movements. In the United States and western Europe, the battered-women's movement was a prominent component of second-wave organizing. The first women's crisis centers were survivor-led grassroots organizations. The provision of shelters - secret safe houses where women victims of domestic abuse could take temporary refuge-was central to these early campaigns. Elsewhere, women's groups organized around local manifestations of violence - in India around campaigns against dowry deaths; in Latin America against the state-sanctioned violence perpetrated by authoritarian regimes.

Until the late 1980s, gendered violence was a feminist issue and was not regarded with much seriousness at the international level. In the late eighties and early nineties this changed, when, due to the efforts of activists of the international women's movement, the framing of violence against women went global. ${ }^{4}$ In their influential account of the development of transnational advocacy networks (networks of activists that coalesce and operate across national frontiers), Margaret Keck and Kathryn Sikkink (1998) explain how the issue achieved such currency. Violence against

${ }^{4}$ The UN Convention on the Elimination of All Forms of Discrimination against Women (CEDAW), which was adopted in 1979 and entered into force in 1981, makes no mention of violence, rape, abuse, or battery. However, by mid-1995 violence against women had become a "common advocacy position" of the women's movement and the human rights movement (Keck and Sikkink 1998). 
women emerged in the 1980s as a framing that had the power to unite women from the North and South. Until that point, attempts to unify in global campaigns had been largely unsuccessful. Women's activists of North and South had been deeply divided and unable to achieve a common agenda. While Northern (or "first-world") feminists had been preoccupied with issues of gender discrimination and equality, Southern (or "third-world") women were more concerned with issues of social justice and development, which affected both men and women, albeit in different ways. Violence against women was a framing that could encompass a broad range of practices and hence bring about dialogue between women from different locations.

Its success at the international level was largely due to the innovation of linking women's rights to human rights, bringing together two powerful constituencies for the first time-human rights activists and feminists. Feminist activists first pushed the issue to international prominence at the 1993 Vienna UN human rights conference. Their strategizing coincided with international concern about the systemic use of rape in war in Bosnia, and it was effective. In 1994, the UN High Commission on Human Rights appointed the first special rapporteur on violence against women, and the Hague Tribunal recognized rape in warfare as a crime against humanity.

The UN Fourth World Conference on the Status of Women in Beijing, 1995, was a pivotal moment for the success of the framing. Combating violence against women emerged as a central policy agenda both of the international women's movement and of international development. The campaigns have galvanized support across diverse constituencies, among politicians and donors. In the late eighties major U.S. foundations decided to make violence against women a funding priority, channeling funds to NGOs that address the issue. ${ }^{5}$ As one American male coordinator of a crisis center training I attended explained to his Russian trainees, "[In the United States] we've found that domestic violence is an easy theme to go to the public with. People give readily. We're at the point where it's politically correct to support this type of organization."

Clearly there is much to celebrate here. Indeed, many feminist scholars regard the prominence of the campaigns as an unqualified success. The campaigns have been analyzed in terms of the increased influence and effectiveness of transnational social movements (TSMs), or transnational

\footnotetext{
${ }^{5}$ The Ford Foundation played a significant role in determining patterns of funding and led the way in funding campaigns against violence against women. While in 1988 major U.S. foundations awarded eleven grants totaling $\$ 241,000$, in 1993 they made sixty-eight grants totaling $\$ 3,247,800$ (Keck and Sikkink 1998, 182).
} 
advocacy networks (TANs). ${ }^{6}$ Such accounts are in keeping with celebratory accounts of NGOs and civil society; here, TSMs represent the positive, liberatory side of globalization. However, there are alternative, less sanguine ways to view this.

While it is true that transnational campaigns such as these unite women's groups across different locations, they do so at a cost. Anthropologist Aihwa Ong provides a critical reading of the "strategic sisterhood" that is the basis of this and other North-South alliances in the post-Beijing conference era. She presents it as an alliance driven by the desire of Northern women that ignores geopolitical inequalities and that is insensitive to non-first-world cultural values. She argues that transnational campaigns are based on a distinctly individualist formulation of "rights" that is Western-specific. ${ }^{7}$ The skepticism among activists that I detected in my research points toward similar frustrations in the postsocialist context.

Building on this and other critiques, I wish to introduce a note of caution in my account of the campaigns. First, I suggest that the very success of the framing can also be regarded as its weakness. Although the framing certainly yields cross-cultural clarity, it does so at a cost. At the transnational level, it works insofar as it is a catchall. However, this catchall quality screens out crucial nuances in the ways people define violence against women in different local contexts. In this article, I will go on to argue that in postsocialist "democratizing" contexts, as in "developing" ones, the framing deflects attention from issues of redistributive justice.

Second, it is important to consider the political economic context of the campaigns. The issue achieved prominence at a time of crucial shifts in global development agendas. The rise of NGOs and the success of the campaigns took place at a time when a neoliberal vision of development has achieved hegemony. This has introduced "a new kind of relationship between the state and civil society and advanced a distinctive definition of the political domain and its participants-based on a minimalist conception of both the state and democracy" (Alvarez, Dagnino, and Escobar $1998,1)$. Concerns about these processes have been raised by both schol-

\footnotetext{
' See Keck and Sikkink 1998. Sperling, Ferree, and Risman provide a nuanced account of Russian women's activism in the context of the development of the transnational women's movement, bringing the lens of new social movement theory to bear on the changes of the early to mid-1990s. Their study documents the first phase of Western donor support to Russian women's groups in the early to mid-1990s (2001).

7 Drawing on data from China, Indonesia, and Malaysia, Ong gives examples of alternative strategies (1996). Gayatri Chakravorty Spivak has made a similar critique of the Beijing conference and its colonialist characteristics (Spivak 1996).
} 
ars and activists, in Southern or "developing" contexts as well as in the postsocialist one. ${ }^{8}$ Support for NGOs is provided within this new rubric and comes with strings attached; NGOs that accept donor support are required to take on the responsibilities of the retreating state, picking up the slack for the radical free market. ${ }^{9}$ What is more, the sudden influx of grants and funding brings about dramatic changes in organizing. Ironically, "NGO-ization" has demobilized social movements. It has contributed to the formation of new hierarchies and allowed former elites to flourish. In many cases it also signals the triumph of Washington- or Geneva-based agendas over local concerns. ${ }^{10}$

The gendered violence campaigns do not operate outside this political economic context. Indeed, the forces that enable them, the logic that drives them, and their effects demonstrate their complicity. Concern about violence against women originated in the second-wave political slogan "the personal is political," which challenged the inviolability of the home and politicized it. However, the radical critique of patriarchy and genderbased economic inequality that was fundamental to the battered-women's movement in the United States and western Europe has fallen out of the transnational campaigns. In a grotesque inversion, the campaigns reprivatize the problem of domestic violence by focusing on interpersonal relations between spouses to the exclusion of structural factors outside, specifically the economic upheavals that most women believe pose the greatest threat to themselves and their families. ${ }^{11}$ In a disturbing way, the work of the campaigns thus overlaps with the privatizing intent of neoliberalism. Indeed, this helps to explain the success of the issue among donors in the West. It is easier to garner support and international outrage around issues concerning sex and that position women as victims than around issues of social justice (Snitow 1999).

${ }^{8}$ See, e.g., Feldman 1997; Lang 1997; Alvarez 1998; Paley 2001; Kamat 2002.

9 Sonia Alvarez, Evelina Dagnino, and Arturo Escobar introduce the concept of "apparatuses and practices of social adjustment (APSAs)" to describe the new service-oriented NGOs that are encouraged into being by international foundations and donor agencies. They regard them as Band-Aids or palliatives, hopelessly compromised by the role they play in stopping up the gaps of the free market $(1998,22)$.

${ }^{10}$ For discussions of how this has influenced women's movements, see, e.g., Lang 1997 and Alvarez 1998; for a consideration of these issues in the formerly socialist states of central and eastern Europe and the former Soviet Union, see Abramson 1999; Snitow 1999; Richter 2000; and Sperling 2000.

${ }^{11}$ I am grateful to Michele Rivkin-Fish for suggesting this formulation. 
Accounting for the rise of crisis centers in Russia: Foundations, funding, and feminists

For complex reasons, violence against women is not an issue that local groups were likely to have raised by themselves. The meeting of Western feminists and Russian women activists in the early 1990s discursively created the issue. These feminist-oriented Russian women set up the first crisis centers, first in Moscow and St. Petersburg, then in provincial cities. In the decade of their existence- - a decade of rapid and tumultuous transformations in Russia-the crisis center network has undergone significant change. Donor support has been a key factor in its development, and feminist-oriented Russian activists have played a crucial role as brokers of ideas.

Since their arrival in Russia in the early 1990s, donor agencies have channeled a proportionally small but ideologically significant portion of civil society aid to women's groups. They met with a diverse range of women's organizations. While some were set up during the mid-1980s, when Mikhail S. Gorbachev's liberalizing reforms permitted the formation of independent groups for the first time, most were founded in the early to mid-1990s in response to the dislocations of the market I have described. While some had their roots in official Soviet era women's organizations (zhensovety), others regarded themselves as determinedly independent from the former regime. A small but prominent minority identified as feminist. These groups of highly educated women were mostly clustered in institutes and universities. Familiar with Western academic literature, they brought insights from Western feminism to bear on Soviet gender relations and on the effects of political and economic reform. They were also committed to practice and spearheaded attempts to bring about unity among women's groups, organizing two Independent Women's Movement forums in 1991 and 1992. This latter group found itself particularly well positioned to take advantage of the new opportunities of democratization aid. Members' knowledge of foreign languages, experience of travel, and familiarity with liberal democratic and Western feminist concepts made for easy dialogue with the representatives of donor agencies. The crisis centers they founded, often in collaboration with Western feminist activists, were greeted enthusiastically by international donor agencies and were among the first women's projects to receive support.

However, while these initiatives won a great deal of international attention, they were less successful at home. The Independent Russian Women's Movement was marginal in Russia and did not have broad support. On the contrary, most men and women regarded women's groups with suspicion and hostility, particularly those that identified as "femi- 
nist." ${ }^{12}$ For complex reasons, there is no commonly shared perception of gender discrimination in Russia or other former socialist states. As many scholars have noted, the commonly held notion is that the socialist state "spoiled" both men and women, emasculating men and making women too aggressive and assertive, denying them natural expression of difference and self-realization (samorealizatsiia). ${ }^{13}$ Men and women perceived themselves to be equally victimized by the state. As Peggy Watson puts it, "Under state socialism, society was excluded as a whole, and citizens, far from feeling excluded relative to each other, were held together in a form of political unity" $(1997,25)$.

I found that among feminist-oriented women's projects, crisis centers were regarded with particular incomprehension and skepticism. Indeed, even some women activists involved in the campaigns admitted that they did not think gendered violence was the most pressing issue facing Russian women and expressed concern that so many resources were put into it.

There was plenty of conflict in the private realm in the USSR. However, women with violent spouses were unlikely to recognize their experience in terms of gendered violence. Crisis centers are premised on a set of property relations that are bourgeois and on an alignment of public and private that is liberal democratic. They presume that women are both economically dependent on men and stuck in the private sphere. This was not true for Soviet women, who were brought into the workforce and guaranteed formal equality by the socialist "paternalist" or "parent" state (Verdery 1996, 63). Soviet-era property arrangements also complicate the picture. The nationalization of all property meant that there was no ideology of private ownership to give Soviet citizens the illusion of domestic inviolability. Many Soviet citizens lived in the notorious communal apartments, sharing kitchen and bathroom facilities with their neighbors. What is more, few married couples lived autonomously as nuclear families. Chronic housing shortages meant that many people lived with extended family, grandparents, in-laws, and siblings. For all these reasons, domestic conflict most commonly expressed itself in the form of tension over rights to living space, interpersonal strife, or alcoholism. Although patterns are certainly changing with the introduction of a free market, lack of housing

12 Another explanation for this skepticism is that women's organizing was enforced and managed from above by the Soviet state, in a network of official women's departments and councils. Further, feminism was discredited by Bolshevik and Soviet leaders, who labeled it a Western reformist phenomenon (Noonan and Rule 1996, 77).

${ }^{13}$ For discussions of state socialist gender arrangements and the corresponding absence of a sense of gender discrimination, see Verdery 1996; Watson 1997; and Gal and Kligman 2000 
remains the most chronic problem. Indeed, this helps to explain why women's shelters have not taken off in Russia. ${ }^{14}$

A further obstacle to crisis centers has been the fact that during state socialism the private sphere was constituted as a kind of "refuge" for both men and women. It was considered to be a site of authenticity against the morally compromised public sphere, and women and men alike jealously guarded its integrity (Verdery 1996). Today, the private sphere remains a (reconstituted) refuge for most Russian people, a site of precious and sustaining networks that offset the violence and chaos that is perceived to be "outside" (mafia, crime, corruption, poverty). Despite the fact that levels of familial violence appear to have increased in the post-Soviet period, most women do not consider it the most pressing problem. ${ }^{15}$ Furthermore, as many crisis center workers acknowledge, Russian women who have experienced sexual or domestic violence are commonly mistrustful of attempts from outside to intervene.

Until 1995, crisis centers were marginal offshoots of the Independent Russian Women's Movement, and although they were celebrated in international circles, their work was little understood at home. Despite this lack of fit, in the midnineties the antiviolence campaigns in Russia underwent a qualitative shift. As "violence against women" became an international development issue, more funds were allocated to it and crisis centers moved from being small, rather peripheral offshoots of the women's movement to become third-sector heavyweights, a central plank of the independent women's movement and a showpiece of foundationNGO relations. ${ }^{16}$

The transnational campaigns brought a key resource to Russian women's groups-a model around which to organize. This model is accompanied by skills and methods that can be transferred and taught. For activists, the crisis center model offers a blueprint and a framework. Neat, easy to learn, it has become a kind of do-it-yourself NGO kit. Foundation

${ }^{14}$ I met many crisis center activists who were keen to establish shelters. However, they acknowledged that local conditions did not permit it. First, there was the difficulty of obtaining premises from local authorities. Second, it was unclear where to relocate women once they had been admitted. If in western Europe and the United States the shelter is a temporary refuge, a stopgap for women and their families before they find their feet, in Russia people have quite literally nowhere to move on to.

15 According to data published in 1995, 14,400 cases of rape were recorded in the Russian Federation in 1993. In the same year, 14,500 women were reported to have been murdered by their husbands or male partners (Attwood 1997, 99).

${ }^{16}$ Foundation representatives I spoke with frequently cited the crisis center network as one of the most successful women's NGO projects. 
support has financed the production of easy-to-use materials-brochures, posters, and handbooks, including one titled "How to Create a Women's Crisis Center." ${ }^{\prime 7}$ The Moscow-based network offers trainings, assisted by foundation support. These teach not only crisis counseling and nondirective listening skills (the hallmark skills of crisis centers) but also management, NGO development, and public relations.

Russian crisis centers have adopted what they call the "international model" and work to a specific set of standards. Through telephone hotlines and individual consultations, they provide free and confidential legal and psychological counseling to female victims of sexual or domestic violence. Counselors undergo eighty hours of training, run by staff of the most experienced centers with input from feminist psychologists, scholars, and lawyers.

What does all this mean to Russian activists? While I insist on the need to situate my study of Russian crisis centers within this "broader political geography" (Gal and Kligman 2000, 4), I do not mean to suggest that the global blocks out the local, or to describe the flow of ideas as unidirectional. Recent scholarship of globalization has argued persuasively against this kind of determinism, and feminist scholars are prominent in the discussion. ${ }^{18}$ Russian women activists draw on international aid and Western models as resources, translating them as necessary. In the process, projects and campaigns are transformed, not imported statically. How do these "traveling discourses" (Gal and Kligman 2000) arrive, what are the processes of "translation" they undergo (Tsing 1997), and with what do they interact as they are "glocalized"?

In the course of my research during 1995-97, I found that the notion of crisis center did have a kind of local resonance. Once again, the violence against women framing caught on because of its catchall quality. Here, however, the keyword was not violence (nasilie) but crisis (krizis). One of the things that struck me in the course of my research was the ubiquity of the notion of crisis center (krizisnyi tsentr). I came across many women (out of the loop of trainings and unfamiliar with the international model) who expressed their intent to set one up or described their work (unconnected with sexual or domestic violence) to be "something like a crisis center." I came to relate this rhetorical persistence to the fact that the whole of Russian society is perceived to be in crisis-with good cause. In

17 The Canadian Embassy funded the publication of the book. According to one of its Russian authors, five thousand copies were distributed to nascent crisis centers and women's NGOs (Zabelina 1996).

18 See, e.g., Grewal and Kaplan 1994 and Gibson-Graham 1996. 
addition to the perception of social and economic breakdown, the Russian crisis is also perceived to be a psychic condition-there is a great deal of talk about the neuroticization of society.

\section{The perspective from the provinces: Competing crises and the displacement of the economic}

Zhenskii Svet (Women's Light) is a small university-based women's group, dedicated to women's education and consciousness-raising. It was founded in the provincial city Tver' in 1991, long before the arrival of Western foundations, in the first wave of independent organizing in Russia. Its founder was Valentina, a professor of history and one of Russia's few selfidentified feminists, who had written her dissertation on the Western women's movement. ${ }^{19}$ One of the reasons I originally made contact with this group was because it claimed to have a crisis center. ${ }^{20}$ However, I arrived to find that this was not so. While the notion of crisis center did exist within the group, it had not quite taken root. The idea had first been introduced to the group in 1992 by some visiting German feminists; however, the project collapsed when the Germans failed to secure funding, and local interest had since waned. When I asked group members about this, they told me that sexual and domestic violence was something they had not really thought much about. It was a terrible thing, but they did not feel any real connection to it. They also insisted that women would not come together around this issue, because it was too private. They could not see how such a project could work in Tver'.

However, the idea of crisis center had remained in the group, in diffuse forms. Lydia was the custodian of one of these crisis center plans. An unemployed woman in her fifties, she attended Zhenskii Svet regularly. I met frequently with her in the course of my stay in Tver' in 1997. Lydia explained that she was not concerned with dealing with the women victims of sexual violence. She intended her crisis center, or "anti-crisis center" (anti-krizisnyi tsentr) as she preferred to call it, to be a service to assist women who encounter economic discrimination (ekonomicheskaia diskri-

\footnotetext{
19 Its feminist and democratic orientation made the group unusual. However, it can be considered exemplary of the early clubs and groups founded in academic circles by women familiar with feminist texts and the Western women's movement.

${ }^{20}$ I first learned about the group in 1995 from the Network of East-West Women electronic listserv. New women's groups, which had just been hooked up to the Internet, announced and introduced themselves and listed their interests. Groups tended to make broad declarations rather than itemize existing services. This was very much of the times, before the standardization associated with NGOs had become widespread.
} 
minatsiia) or (gendered) discrimination in the workplace. This was a new term to refer to a new phenomenon, since the Soviet regime had an ideological commitment to both full employment and gender equality. She understood that in the United States and western European countries a crisis center was a service for the victims of sexual and domestic violence but argued that in Russia such a conception did not make sense. She insisted that although sexual violence was indisputably a terrible thing, it was a much less widespread problem than economic violence and discrimination, which touched almost every woman's life.

As I pieced her story together, I came to regard it as a classic survivor's narrative. She had encountered "discrimination" in her own life and now wanted to set up a service to assist women in similar situations. Two years ago, before I met her, Lydia was pressured to quit her job as a sociological analyst at the Federal Employment Service when initially generous state funding was cut back. Forced to make layoffs, her boss began to exert pressure (davlenie) on some members of the staff to leave-to leave, as it were, of their own volition (so that her boss could avoid paying unemployment benefits). Although both men and women staffed the office, he targeted the women in the group. Lydia experienced this as a profound shock, a profound "crisis," as did her female colleagues, who went through the same process. She told me that it was the first time she and her coworkers had had to face the idea of unemployment. She was shocked at the callous disregard of her rights. She was shocked at how her boss, a former military officer, she emphasized, had "pressed" her to leave. Agitated by the memory, she told me that the pressure was so intense that one woman had been "on the verge of a heart attack." Lydia's account evoked the profoundly destabilizing social dislocation she and her colleagues had experienced at this time. Unemployment was not merely distressing to her on account of the financial burden it placed on her but because it was an attack on her dignity, on her very identity, her sense of self. It also cast a blow to her worldview. She was shaken by the fact that a person of education and high social standing (an officer) had behaved in this way.

In many ways, Lydia's story is paradigmatic of women's early nongovernmental organizing in Russia. Regardless of how they described themselves, of the educational levels of their members, of their location or ideological hue, in the early 1990s women's groups were engaged in a common purpose. They were survival mechanisms, set up for and by women who were hard hit by social and economic reform. Involvement in this activity goes beyond a concern with the gendered effects of the market and is frequently driven by a generalized perception of material, 
moral, and psychological crisis. In their different ways, these organizations have taken on the challenge of creating new forms of social solidarity and togetherness following the collapse of the Soviet collective.

Although Lydia's conception of crisis center emphasized structural factors-economic violence attributable to the market and shock therapy and their gendered effects-hers was neither a straightforwardly "feminist" nor anticapitalist construction. Indeed, she did not address her sense of discrimination toward men as a group or toward the institutions whose policies contributed to it (the International Monetary Fund and the Russian government). Instead, she addressed herself to the absent, retreating Soviet state. She had been able to find a state agency that had overturned the decision. Although she had not been awarded material compensation, she had received symbolic recognition of the injustice of her dismissal. She intended her crisis center to be a project that would provide similar assistance to local women.

Lydia's case perhaps looks idiosyncratic. In many ways, she represents a prior understanding of crisis center, one that preceded the arrival of foundation support. However, I found echoes of her understanding elsewhere. Between 1995 and 1997, before the action research project in Tver', I visited crisis centers in St. Petersburg and several provincial cities. These visits provided alternative insights and left me with quite different impressions of the antiviolence campaigns than those I received in Moscow. Despite the fact that they formally adopt the crisis center model (i.e., the "international standard"), many of these centers had much broader programs in response to local needs. As the director of one provincial crisis center said to me over coffee, "We go to these Moscow-based seminars, workshops, and conferences, but our agendas are still driven by local concerns." Because these centers are raising the issue of violence against women for the first time, only a relatively small proportion of clients call to discuss it. All the counselors I spoke to confirmed that when they first set up, a wide range of people called their hotlines. Men called as well as women and, strikingly, a lot of pensioners-in sum, those who felt marginalized and vulnerable. I was told that people called to speak about diverse issues - unemployment, unpaid wages, loneliness, alcoholism, loss of children to the military service, as well as domestic or sexual violence. As one St. Petersburg-based activist put it, "there is great confusion now, the old system is broken down, but it's not clear what is emerging. People are confused, and there is a great demand for information. They don't know what to ask for, who to speak to, how to name their problems." Centers have responded to this in different ways; some speak to all callers, others only to women victims of violence. One center in Sergiev-Posad 
abandoned its women-only focus for a few years in response to local incomprehension.

Counselors in all the centers I visited informed me that women who do call to speak about gendered violence frequently relate it to a range of other materially based issues, such as unemployment, impoverishment, and cramped living space. In response to this, counselors focus on the woman in broader social context, particularly on the family. Activists in provincial cities, where they may provide the only women-oriented services, conclude that it makes no sense to specialize too narrowly. They say it is impossible to separate the problem of domestic or sexual violence from other issues women face. In general, counselors afford a high priority to clients' material problems. In one St. Petersburg center, survivor support groups place great emphasis on practical steps women can take, sometimes resulting in members of a group going into business together.

These constructions could work to inform the work of the transnational feminist movement; these critiques could be the basis for dialogue. The effectiveness of the global women's movement surely rests on its ability to heed local concerns. As Ellen Dorsey puts it, we need to "carefully tread the line between building common strategies and reflecting the actual concerns and dynamism of the movement on the ground" lest the movement be discredited $(1997,355)$. However, there are some serious systemic impediments. First, the logic of grants and funding encourages groups to adopt the themes and terminologies prioritized by donors, making issues that fall outside this rubric unnarratable. Second, NGO staff and donor representatives are frequently not disposed to listen to these commentaries. ${ }^{21}$ For both these reasons, crisis centers experience great pressure to conform to the "international model."

Furthermore, I found that the rubric of the crisis center and the technologies that accompanied it brought about significant changes in the ways both staff and their clients formulated the problems facing women, making the articulation of critiques and counterstrategies still less likely. In Russia, technologies and methods that are designed to empower women - such as nondirective active listening —ironically work against this insofar as they dissuade clients and counselors from articulating their ma-

${ }^{21}$ I found that many North American or western European feminists dismissed discussions of economic factors as a rationalization for male-perpetrated violence. The standard response was the assertion that rich men also beat their wives. While of course this is true and important, in this context it is extraordinarily dismissive of local concerns and shows little awareness of the extent of economic dislocation in Russia and its devastating effects on the lives of women and their families. 
terial concerns. Techniques of nondirective active listening require callers to come to their own solutions. Crisis centers provide information and consultations (on legal issues and social services) but encourage clients to take part in the defense of their rights and make their own decisions. While most centers offer free legal advice, their main message is frequently what not to expect from the state. The director of one center told me, "Their first question is always, 'What will the state do for me [as a battered woman] if I get divorced?' I explain that they have little realistic chance of getting help." In survivor support groups, she works to make women aware of these material and political issues, to recognize that the state is not going to help them, and that the only way forward is to help themselves.

\section{Tver' and Zhenskii Svet: Adopting the Western model}

This dynamic became clear to me in the course of my interactions with Zhenskii Svet. The action research process that I undertook with members of Zhenskii Svet brought the two models of crisis center I have outlined into competition. ${ }^{22}$ Lydia's "anti-crisis center" for unemployed women was pitched against a "crisis center" for women victims of domestic and sexual violence that accepted the framing of violence against women backed by the transnational campaigns. The latter won out. It won not because it best expressed members' idea of the most important problem facing local women in Tver' but because it was considered most likely to succeed. In crucial ways, as facilitator of the seminar and as a Western outsider with resources to bring to the project, I was the arbiter. ${ }^{23}$ The latter model had two advantages. First, it had broad legitimacy among two key constituencies-Western donor agencies and actors of the local administration. Second, it was organizationally viable. Both characteristics were consequences of international donor involvement and the success of transnational feminist campaigns.

Through the action research project, I was able to lend my energies to the group as it negotiated the contradictory nongovernmental field. In this context, my status as a Western outsider and my familiarity with

\footnotetext{
${ }^{22}$ In brief, participatory action research (PAR) is a social change methodology, involving the participation of a community group in problem posing and solving (Maguire 1987). For helpful discussions of PAR, see, e.g., Fals Borda and Rahman 1991; Maguire 1996; and Greenwood and Levin 1998.

${ }^{23}$ I reflect on my role and the implications of my involvement in this project elsewhere. See Hemment 2000, forthcoming.
} 
donor priorities became a valuable resource that group members were able to deploy. In the course of my fieldwork, I had amassed a great deal of information about women's crisis centers and realized that the network offered great possibilities for provincial women's groups. I shared this information with members of Zhenskii Svet.

Some of the women began to see the founding of a crisis center as a way to strengthen and institutionalize some of the more socially oriented programs offered by Zhenskii Svet. They saw it as a potential base from which already existing projects could be run and as a place where young women could gain work experience. A key player in this project was Oktiabrina, a doctor and one of the newest and most enthusiastic participants of the group. An assertive, practical woman in her midthirties, she had recently moved to Tver' from Siberia with her family when her engineer husband lost his job. She worked part-time at one of the local hospitals, renting office space with another doctor, drawing a meager salary, and offering free seminars in women's health through Zhenskii Svet.

When I met her, she was looking for a niche, a place to which she could bring her considerable energies and that would allow her independence. "I'm not afraid of hard work," she told me, "the main thing is that I am committed to what I do." She dreamed of being able to bring about a unity between what she called her hobby (issues of women's health, the women's movement) and her career. The idea of setting up a crisis center appealed to Oktiabrina because it most closely approximated the "concrete social project" she wanted to be involved in. Her own economic vulnerability meant that she was attuned to the plight of women in the city, and she wanted to do something practical to meet their needs. Furthermore, she was persuaded by the issue of gendered violence. As a doctor, she had noticed that many of her women patients had bruises under their clothes. "It was obvious that some of them had violent spouses, but there was no way to talk to them about it," she said.

In summer 1998, with the endorsement of other members of Zhenskii Svet, Oktiabrina and I embarked on a preparatory project to set up a crisis center for women in Tver'. Our aims were to learn more about existing services and to locate sources of financial and material support. We met with members of the local administration and staff of the local social security services and traveled to Moscow and several provincial cities to visit and learn from other crisis centers. It was a successful strategy. The Tver' project coincided with a specific moment of expansion in the network of crisis centers. It was seeking to reregister itself as a national association and was eager to find more collaborators throughout the Russian Federation. To this end, its sponsors provided start-up funds for new 
centers and were glad to make the acquaintance of a provincial woman activist well versed in the tenets of the international women's movement. At the same time, in Tver' local conditions were ripe. Since the midnineties, "women's issues" have had political currency in Russia. Throughout the regions of the Russian Federation, officials are now mandated to undertake steps to provide services for women. In this way, "crisis center" has entered the lexicon of government officials and social services personnel and is on the books. We won the support of two key political figures in the city - the mayor (who was preparing for reelection) and the president's representative to the oblast' (a woman journalist with an insecure political base who had begun to dabble in the "women's movement" in order to generate support for herself in the city). They were only too happy to make the acquaintance of a community group willing to undertake such an endeavor.

The center set up in fall 1998. Oktiabrina pulled together a group of interested women who were prepared to start work on a voluntary basis and led seminars based on the training she had received in Moscow. At the outset of the project, she acknowledged that she saw setting up a crisis center as a pragmatic move. If it took off, it would make a good umbrella project under which already existing projects could continue to run and new ones could be devised. She saw it as a pilot project through which she could discover what local women perceive their real problems to be.

As I have followed the crisis center over the last four years, I have been able to trace the shifting perceptions of its staff and volunteers. In the first months of its existence, gendered violence was very much on the periphery of the project. The first clients who came to the center were either already personally acquainted in some way with staff members or were chance passersby. These women did not talk about domestic violence but discussed instead a variety of other, mostly materially based problems. When I asked them about their plans for the near future, Oktiabrina and other staff and volunteers talked of setting up a variety of other projects within the center to meet local women's needs-a "work therapy" club (designed to help local women go into business together and consider economic strategies), a social club, and seminars in cosmetology and women's health. Oktiabrina confided that in some ways she regretted focusing so directly on sexual and domestic violence. She told me, "Women who really experience this will rarely come forward to talk about it-I uncover it in conversations, it lies buried, it is very often a source of grief, but in focusing on it, we scare women away."

She gave a very different account when we met in Boston in February 2000 while she was attending a training course for Russian professionals 
working on domestic violence. She exhibited increasing self-confidence, both in her own position and in the validity of the crisis center narrative. She told me that much had changed since a telephone had been installed in August 1999. This enabled the center to finally open a hotline for women (telefon doveriia), and as soon as the service was advertised the center had been inundated with calls. There was a great appetite in the city for telephone hotlines, and (particularly) for free psychological counseling. The hotline is open from nine to six every day except weekends. Oktiabrina told me that they receive between fifty and seventy calls per month, of which between six and fifteen pertain to domestic violence.

I asked her to tell me about the issues clients raised. She told me that many come to discuss problems in their relationships (vzaimootnoshenie) with the people they live with-alcoholism or conflicts over living space upon divorce. I asked her how many of these people had experienced domestic violence. She paused to consider and told me that in each case there is an element of domestic violence. However, this was loosely defined. One woman came to speak of problems with her mother, another about difficult relations with her sister. The rest came to discuss issues with their spouses. She told me that she was surprised that women are willing to come forward and to talk about their problems, however they define them, and that she was surprised too that people do speak about forms of domestic violence. "The need is real," she told me.

She had devised an interesting strategy to overcome the problem of women's reluctance to speak of "domestic violence." Center staff have two distinct modes of representing their work. They advertise the hotline as a generalized service, as a hotline for women (telefon doveriia dlia zhenshchin), "so we don't scare women away." Since fall 1999, the center has run a couple of support groups, which staff advertise as a "support group for women" (gruppa podderzhki dlia zhenshchin), not specifying spousal abuse. When speaking to clients, they avoid terminology that might alienate women; they do not use the term violence (nasilie) or violent behavior (nasil'stvennoe povedenie) but speak instead of controlling behavior (kontroliruiushchee povedenie). Likewise, they do not refer to the violator (nasil'nik) but the offender (obidchik). They discuss the myths (mify) and prejudices (predubezhdeniia) surrounding rape and domestic violence. Meanwhile, they use the language of the campaigns and speak of domestic violence, or violence against women, in their outreach and educational work, for example, when speaking to the media, when lobbying the mayor, and when giving lectures to students of the university, of the police academy, or to lawyers.

Oktiabrina attributed the success of the project to the framing of vi- 
olence against women. As she put it, "It was important for us to define a specific area of activity in order to achieve this. If we had chosen to deal with violence more broadly, or with economic issues, or with alcoholism as some people suggested, we wouldn't have been able to do it." She told me that the main achievement of the last six months is that the center now has a name, an image (imadzh) in the city. She has been able to overcome local skepticism precisely due to the international support that the project has won. The symbolic aspect of this support was as important as the material; she had used it as a bargaining chip in negotiations with local power brokers, and it had won her the grudging support of those who were very skeptical about the issue.

As is clear from her latest account, what appears to have changed most markedly is Oktiabrina's own sense of conviction. Women come with similar problems as previously. However, she is more convinced of the efficacy of her project and more tightly socialized into the campaigns. I tried to push her to reflect on this. What did these shifts in orientation mean to her? I gained no sense that she was torn by these changes. Rather, she was clearly proud of her work and its success. "We've come a long way," she told me, "there used to be no language for this kind of thing. Now the authorities have been forced to recognize the problem."

Our most recent conversations reveal a greater degree of ambivalence. When I last returned in summer 2001, I found Oktiabrina preoccupied with new questions. Although eloquent about the importance of the work she does, she was alive to its contradictions and eager to discuss the ambivalence of collaboration with donor agencies. Together with Lena, a crisis center colleague from a neighboring city, we discussed these issues. In the course of our conversation it became clear that the two women were dissatisfied and baffled by foundation policies and felt unheard by foundation representatives. Although they felt that they were doing useful work, they were frustrated that bureaucratic activities took up so much time. What is more, they felt constrained. Grants permit and exclude specific activities, down to the themes of trainings. Lena explained that agency evaluators had recently visited her center and it was absolutely clear to her that they were not interested in the content of the center's activities; "they just need pretty numbers, they don't need to hear my thoughts (razmyshlenie) about our work." Further, they were concerned that donors were moving away from supporting the theme of nasilie (violence). The new theme, she continued, was torgovlia liud'mi (trafficking). Oktiabrina nodded, saying, "We have to be like chameleons to please the foundations. Even if you don't want to take it [trafficking] on, you have to!"

Finally, they had begun to feel a sense of futility about the work they 
had been encouraged into. They had successfully raised an issue that both felt was real and important, but at the same time they were aware that it was nested within a host of other concerns. As with the other crisis centers I came across, they found that their clients came to discuss a wide variety of issues. Although they were frequently able to locate (or "uncover") an element of domestic violence in clients' accounts (whether it was verbal or psychological abuse, economic pressure, or actual physical violence carried out by spouses or male relatives), clients most pressingly made reference to material problems that affected both them and their families. Their work with women uncovered issues that they felt powerless to address-problems connected with unemployment, unpaid wages, and the crisis of living space. "All we can offer is psychological support. It doesn't resolve the main issues," Oktiabrina lamented, "We can't solve the material problems." Lena agreed, saying, "The global attention to solving women's problems must be the business of the government! Housing, the police, the law-it's too much on our shoulders!"

\section{Conclusions}

In this account so far, I have tried to convey the local meanings that get screened out by the international renditions of the violence-againstwomen campaigns. So what lessons for the transnational women's movement can we draw from this specific case?

While it is important to celebrate the success of the crisis center network in terms of the economic and political opportunities it provides local women, we also need to critically interrogate the success of the campaigns and to be aware of their discursive effects. Within contemporary conditions of globalization, transnational gender politics operates as a mode of power that constitutes some women and some issues as deserving, excluding others (Mindry 2001). Indeed, understanding these effects helps us interpret the skepticism of some of the women involved in the campaigns, such as the activist whose comments I began with.

Skepticism about these campaigns testifies to the fact that many people experience these campaigns and similar ones as primitivizing. Since the fall of the Soviet Union, "violence against women" has become an international development issue, a marker to gauge the "civilization" of states. According to this yardstick, despite the collapse of the political, military, and conceptual boundaries of the cold war, Russia remains as far away from the West as ever before. In fact, ironically, rather than drawing closer, it has slipped backward (from Soviet gender equality to a place of "uncivilized" gender relations). I believe that it was precisely this discursive 
effect that many of my interlocutors objected to. Furthermore, the framing used by the international campaigns has the ideological effect of obscuring the fact that violence against women is structurally endemic within liberaldemocratic capitalist regimes. It is not so much the case that liberal democratic "civil" society is not violent but that the system allows for the existence (and occasionally encourages the provision) of services to mop it up. Making gender and violence a marker of development obscures a fact that both crisis counselors and their clients know very well-that all forms of violence, including gendered violence, have been exacerbated by structural adjustment, the very liberalizing project that was supposed to bring civility to Russia. No wonder those engaged in the ideological work of these campaigns feel ambivalent about them.

The discursive prominence of terms such as crisis center and violence and their prioritization exemplifies some troubling aspects of Western democratization aid. The prominence of the issue of violence against women can be read as part of a broader trend, marking a discursive privatization of the social dislocation accompanying transition and a depoliticization of the economic. Stopping up the gaps of the radical free market, services such as crisis centers act as mediators, educating Russian people into the new order. The individualizing, economizing discourses that these centers put out ("self-help," "self-reliance") educate people out of politics, out of expecting anything from the crumbling and retreating state. The winning out of the "international model" marks an abandonment of attempts to tackle structural problems, as my examples from Tver' reveal. Interestingly, both Oktiabrina's and Lydia's crisis center projects foreground issues of individual change and development rather than structural issues, and there is little critical discussion of the path of democratization and development. One of the last things Oktiabrina said to me was that women needed to be educated out of the "myth" that domestic violence has material roots. Here, she was making the feminist argument that domestic violence could not be justified as a response to economic hardship. Still, in her ready adoption of this framing, I see her as still taking on the old socialist state and its discredited, materialist ideologies, perhaps not fully aware of the implications of the new ideology that is taking its place. Meanwhile, over time the element of structural critique dropped out of Lydia's "anti-crisis center" plan. Whereas formerly she had at least implicitly addressed the state and the illegality of economic discrimination and dismissals, she began to speak only in terms of psychological support. Her new project description was "to afford psycho- 
logical support to women who are suffering the consequences of loss of work." 24

However, this is not the full story. My Tver' case study shows how the model of crisis center has been appropriated and embraced and deployed to various different ends. The women of Zhenskii Svet, like many other activists, made a pragmatic, strategic decision to set up a crisis center. They were to some extent coerced into the framing, yet they have been able to reappropriate it in key ways. The crisis center meets group needs and objectives that preceded the arrival of Western funding. It has become an important discursive site where social dislocation and confusion are explored and made sense of, where needs can be defined and named, and survival strategies formulated. Like other NGOs, it is a dynamic site in which people negotiate the past and the present. No less significantly, it serves as an effective niche, a foothold for those who work there, and contributes to the creation of new forms of solidarity and togetherness. What's more, crisis centers bring nongovernmental women's activists into dialogue with state agencies, contributing to important realignments between spheres.

I regard my colleagues' appropriation of the model as an ambivalent thing - it is part co-optation, part self-justification, and part testimony to a new formulation of gendered violence. Work conducted in the center both embraces and exceeds the gendered violence narrative. In their commentaries I see the germ of a critique and the potential formulation of a collective, or at least less individualistic, response to gendered violence that could be useful to us all.

Department of Anthropology

University of Massachusetts, Amberst

\section{References}

Abramson, David. 1999. "A Critical Look at NGOs and Civil Society as Means to an End in Uzbekistan." Human Organization 58(3):240-50.

Alvarez, Sonia E. 1998. "Latin American Feminisms 'Go Global': Trends of the 1990s and Challenges for the New Millennium." In Cultures of Politics, Politics of Cultures, ed. Sonia E. Alvarez, Evelina Dagnino, and Arturo Escobar, 293-324. Boulder, Colo.: Westview.

Alvarez, Sonia E., Evelina Dagnino, and Arturo Escobar. 1998. "Introduction:

\footnotetext{
${ }^{24}$ During my last trip to the city in 2001, I learned that Lydia had been appointed director of a newly founded, government-funded Center for Women and Families.
} 
The Cultural and the Political in Latin American Social Movements." In Cultures of Politics, Politics of Cultures, ed. Sonia E. Alvarez, Evelina Dagnino, and Arturo Escobar, 1-25. Boulder, Colo.: Westview.

$\rightarrow$ Attwood, Lynne. 1997. "'She Was Asking for It': Rape and Domestic Violence against Women." In Post-Soviet Women: From the Baltic to Central Asia, ed. Mary Buckley, 99-118. Cambridge: Cambridge University Press.

Berdahl, Daphne. 1999. Where the World Ended: Reunification and Identity in the German Borderland. Berkeley: University of California Press.

Borneman, John. 1992. Belonging in the Two Berlins: Kinship, State, Nation. Cambridge: Cambridge University Press.

Bridger, Susan, Rebecca Kay, and Kathryn Pinnick. 1996. No More Heroines? Russia, Women and the Market. London: Routledge.

Dorsey, Ellen. 1997. "The Global Women's Movement: Articulating a New Vision of Global Governance." In The Politics of Global Governance: International Organizations in an Interdependent World, ed. Paul F. Diehl. Boulder, Colo.: Lynne Rienner.

Escobar, Arturo. 2000. "Culture Sits in Places: Anthropological Reflections on Globalization and Subaltern Strategies of Localization." Paper presented at Five Colleges Faculty Symposium on Globalization, Postdevelopment, and Environmentalism, June 1-3, 2000, at Hampshire College, Amherst, Mass.

Fals Borda, Orlando, and Muhammad Anisur Rahman, eds. 1991. Action and Knowledge: Breaking the Monopoly with Participatory Action Research. New York: Apex.

$\rightarrow$ Feldman, Shelley. 1997. "NGOs and Civil Society: (Un)stated Contradictions." ANNALS, AAPSS 554 (November): 46-65.

Gal, Susan, and Gail Kligman. 2000. The Politics of Gender after Socialism. Princeton, N.J.: Princeton University Press.

Gibson-Graham, J. K. 1996. The End of Capitalism (as We Knew It): A Feminist Critique of Political Economy. Cambridge, Mass.: Blackwell.

Greenwood, Davydd, and Morten Levin. 1998. Introduction to Action Research. London: Sage.

Grewal, Inderpal, and Caren Kaplan, eds. 1994. Scattered Hegemonies: Postmodernity and Transnational Feminist Practice. Minneapolis: University of Minnesota Press.

Hemment, Julie. 2000. "Gender, NGOs and the Third Sector in Russia: An Ethnography of Russian Civil Society.” Ph.D. dissertation, Cornell University.

—. Forthcoming. "Strategizing Development: Translations, Appropriations, Responsibilities." In Post-Soviet Women Encounter Transition: Nation Building, Economic Survival, and Civic Activism, ed. Kathleen Kuehnast and Carol Nechemias. Washington, D.C.: Woodrow Wilson International Center for Scholars Press.

Kamat, Sangeeta. 2002. Development Hegemony: NGOs and the State in India. Oxford: Oxford University Press. 
Keck, Margaret E., and Kathryn Sikkink. 1998. Activists beyond Borders: Advocacy Networks in International Politics. Ithaca, N.Y.: Cornell University Press.

Lang, Sabine. 1997. “The NGOization of Feminism.” In Transitions, Environments, Translations, ed. Joan W. Scott, Cora Kaplan, and Debra Keates, 101-20. New York: Routledge.

Maguire, Patricia. 1987. Doing Participatory Research: A Feminist Approach. Amherst: University of Massachusetts Center for International Education.

$\rightarrow$ _ 1996. "Considering More Feminist Participatory Research: What Has Congruency Got to Do with It?” Qualitative Inquiry 2(1): 106-18.

$\rightarrow$ Mindry, Deborah. 2001. "Nongovernmental Organizations, 'Grassroots,' and the Politics of Virtue." Signs: Journal of Women in Culture and Society 26(4): 1187-1212.

Noonan, Norma C., and Wilma Rule, eds. 1996. Russian Women in Politics and Society. Westport, Conn.: Greenwood.

$\rightarrow$ Ong, Aihwa. 1996. "Strategic Sisterhood or Sisters in Solidarity? Questions of Communitarianism and Citizenship in Asia." Indiana Journal of Global Legal Studies 4(1):107-35.

Paley, Julia. 2001. Marketing Democracy: Power and Social Movements in PostDictatorship Chile. Berkeley: University of California Press.

Richter, James. 2000. “Evaluating Western Assistance to Russian Women's Organizations." In The Power and Limits of NGOs: A Critical Look at Building Democracy in Eastern Europe and Eurasia, ed. Sarah E. Mendelson and John K. Glenn, 54-90. New York: Columbia University Press.

Snitow, Ann. 1999. "Cautionary Tales.” In Proceedings of the 93rd Annual Meetings of the American Society of International Law, 35-42. Buffalo, N.Y.: W. S. Hein.

Sperling, Valerie. 2000. Organizing Women in Contemporary Russia: Engendering Transition. Cambridge: Cambridge University Press.

$\rightarrow$ Sperling, Valerie, Myra Marx Ferree, and Barbara Risman. 2001. "Constructing Global Feminism: Transnational Advocacy Networks and Russian Women's Activism." Signs 26(4):1155-86.

Spivak, Gayatri Chakravorty. 1996. “'Woman' as Theatre: United Nations Conference on Women, Beijing 1995.” Radical Philosophy 75 (January-February): $2-4$.

Tsing, Anna Lowenhaupt. 1997. "Transitions as Translations." In Transitions, Environments, Translations: Feminisms in International Politics, ed. Joan W. Scott, Cora Kaplan, and Debra Keates, 253-72. New York: Routledge.

Verdery, Katherine. 1996. What Was Socialism, and What Comes Next? Princeton, N.J.: Princeton University Press.

Watson, Peggy. 1997. "Civil Society and the Politics of Difference in Eastern Europe." In Transitions, Environments, Translations, ed. Joan W. Scott, Cora Kaplan, and Debra Keates, 21-29. New York: Routledge. 
Wedel, Janine. 1998. Collision and Collusion: The Strange Case of Western Aid to Eastern Europe, 1989-1998. New York: St. Martin's Press.

Zabelina, Tat'iana. 1996. "Sexual Violence towards Women." In Gender, Generation and Identity in Contemporary Russia, ed. Hilary Pilkington, 169-86. London: Routledge. 